DOI: $10.38136 /$ jgon. 854818

\title{
Evaluation of platelet indices in patients with preeclampsia and gestational hypertension
}

\section{Gestastonel hipertansiyon ve preeklampsi hastalarında platelet indekslerinin değerlendirilmesi}

\author{
Cuma TAȘIN \\ İhsan BAĞLI ${ }^{2}$ \\ Hatun ÇOLAK ${ }^{3}$ \\ Revan Sabri ÇiFTÇi ${ }^{3}$ \\ Hakan AYTAN ${ }^{3}$
}

(1) Orcid ID:0000-0002-9315-4791

(1) Orcid ID:0000-0002-3195-9164

(1) Orcid ID:0000-0003-2560-3142

(1) Orcid ID:0000-0003-2560-3142

(1) Orcid ID:0000-0002-2553-7715

\footnotetext{
${ }^{1}$ Mersin University, Department of Perinatology, Mersin/Turkey

2 University of Health Sciences Diyarbakir Gazi Yasargil Research and Training Hospital, Department of Obstetrics and Gynecology, Diyarbakır/Turkey

${ }^{3}$ Mersin University, Department of Obstetrics and Gynecology, Mersin/Turkey
}

\section{ABSTRACT}

Amaç: Platelet indekslerinden biri olan platelet kütle indeksi (PKI)'nin preeklampsi ve gestasyonel hipertansiyon hastalarında kontrol grubu ile karşılaştırılarak değerlendirilmesini amaçladık.

Gereç ve Yöntemler: Çalışma retrospektif olarak tasarlandı. Ocak 2016 ve Ocak 2020 yılları arasında Mersin Üniversitesi Kadın Hastalıkları ve Doğum kliniğinde takip edilmiş 88 gestasyonel hipertansiyon (GH), 210 preeklampsi (PE),VE 140 sağıkı kontrol hastasının dosyaları tarandı. Platelet sayısı (PS), ortalama platelet hacmi (OPH) değerleri ve platelet sayısı x ortalama platelet hacmi /1000 formülü ile bulunan platelet kütle indeksleri (PKI) gruplar arasında karşılaştıııldı.

Bulgular: PS, PKI ve OPH değerleri gruplar arasında farklı bulundu. Subgrup analizinde, $\mathrm{GH}$ ve kontrol grubu arasında istatistiksel fark bulunmadı. PE grubunda PS, PKI ve OPH ortalama değerleri kontrol grubuna göre istatistiksel olarak anlamlı düzeyde düşüktü ( $p=0.016, p=0.023, p=0.026$ sırasıyla). Preeklampsinin öngörüsü için PKI değerlerinin kesme noktası 2303.35 ml/1000 olarak alındığında PKI'nin sensitivitesi ve spesifisitesi sırasıyla $\% 53.6$ ve $\% 52.6$ olarak bulundu ( $=0.021$ ).

Sonuç: PS, OPH ve ilk kez preeklampsi hastalarında değerlendirilen PKI değerleri preeklampsi hastalarında istatistiksel olarak anlamlı düşük saptandı.

Anahtar kelimeler: Gestasyonel hipertansiyon, preeklampsi, platelet kütle indeksi.

\section{INTRODUCTION}

Systolic blood pressure $\geq 140 \mathrm{mmHg}$ and / or diastolic blood pressure $\geq 90 \mathrm{mmHg}$ after the 20th week of pregnancy is defined as gestational hypertension (GHT) and one positive protein in spot urine or proteinuria above 300 milligrams in 24-hour urine in such patients is called preeclampsia (PE) (1). Approximately $22 \%$ of pregnancies have GHT and PE is diagnosed in
ÖZ

Aim: To assess the predictive role of the platelet indices including platelet mass index (PMI) for the diagnosis of preeclampsia (PE) and gestational hypertension (GTH).

Materials and Methods: This retrospective study was conducted by scanning the files of patients hospitalized between January 1, 2016 and January 1, 2020 in Mersin University Gynecology and Obstetrics clinics; 88 gestational hypertension, 210 preeclampsia and 140 healthy control patients were selected according to the study criteria. Platelet count (PC) and mean platelet volume (MPV) values were obtained from hospital's electronic database. PMI was calculated by the formula PC $x$ MPV/103.

Results: There was a significant difference between groups with respect to PC, PMI and PC/MPV values. When the subgroups were studied, there was no difference between the GHT group and the control group. PC, PMI and PC/MPV mean values in the $P E$ group were significantly lower than the control group $(p=0.016, p=0.023$, $p=0.026$ respectively). Sensitivity and specificity of PMI was found to be $53.6 \%$ and $52.6 \%$ respectively for the prediction of the $\mathrm{PE}$, when the cut-off value of $\mathrm{PMI}$ is taken as $2303.35 \mathrm{ml} / 103$ ( $p=0.021)$

Conclusion: $\mathrm{PC}, \mathrm{PC} / \mathrm{MPV}$ and $\mathrm{PMI}$ were found to decrease significantly in patients with PE, but not in $\mathrm{GTH}$.

Keywords: gestational hypertension; preeclampsia; platelet indices

$7 \%$ of all pregnancies (2). PE and GHT are among the most important problems of the pregnancy period, both associated with increased maternal mortality and morbidity rates (3). Although the exact pathophysiology of preeclampsia is not known, inadequate invasion of trophoblasts into the maternal vascular bed and consequently increased placental blood flow and increased maternal endothelial dysfunction with inflammation are among the known etiologies (4). Platelets take an important role in the 
progression of preeclampsia (5). The thrombocytopenia that occurs reflects the severity of the disease (6). Secondary to thrombocytopenia, new platelet production occurs in the bone marrow (7). In some studies, the volume and indices of these new platelets were found to be related to platelet activity (8). Therefore, some indices are used to predict and monitor the progression of the disease. Platelet count (PC), mean platelet volume (MPV), platelet count / mean platelet volume (PC/MPV) are some of these indices (9). Recently a new platelet index called platelet mass index (PMI), which is calculated by the formula platelet count $x$ mean platelet volume / 103, has been suggested to be closely related to platelet function (10). The role of this index is not known in PE or GHT.

In previous studies, it was reported that platelet indices can be used as PE predictors. In our study we aimed to assess the predictive role of the platelet indices including PMI for PE and GTH by comparing these indices in healthy pregnant women, pregnant women with GTH and PE.

\section{MATERIALS AND METHODS}

The study was conducted by scanning the files of patients hospitalized between January 1, 2016 and January 1, 2020 in Mersin University Gynecology and Obstetrics Department. Diagnoses and groups in patient files were determined as follows; Measured with an interval of 4 hours after the 20th week of pregnancy, women with systolic blood pressure $\geq 140 \mathrm{mmHg}$ or diastolic blood pressure above $\geq 90 \mathrm{mmHg}$ and $>1$ positive in spot urine or $>300 \mathrm{mg}$ protein in 24-hour urine were diagnosed to have PE and selected as "Group 1", women with systolic blood pressure $\geq 140 \mathrm{mmHg}$ or diastolic blood pressure above $\geq 90 \mathrm{mmHg}$ and loss of protein in spot urine $<1$ positive or $<300$ $\mathrm{mg}$ in 24-hour urine were diagnosed to have GHT and selected as "Group 2", pregnant women who were healthy, had no additional disease, had normal blood pressure and protein levels in urine were selected as "Group 3". Patients with a history of thyroid disease, pre-pregnancy hypertension, diabetes mellitus and liver disease were excluded from the study. $88 \mathrm{GHT}$, $210 \mathrm{PE}$ and 140 control patients were enrolled according to the inclusion criteria. Hemoglobin, hematocrit, platelet count (PC) and mean platelet volume (MPV) values were recorded by analyzing hemograms with an automated hematology analyzer (SYSMEX-XN-1000/23797). Demographic data of the patients including age, gestational week of delivery and laboratory results including complete blood count and liver/renal function tests were recruited from the electronic database of the hos- pital. PMI was calculated by multiplying platelet number with MPV and divide the result by 1000 .

\section{Statistical analysis}

Statistical analysis was accomplished by using IBM SPSS version 22.0 statistical program. In One-Way ANOVA, variances were seen to be distributed homogeneously. Normality of the data was tested with Kolmogorov-Smirnov test. Normally distributed data were expressed as mean \pm standard deviation and compared with One Way ANOVA test. Since the number of patients in the groups is different from each other, the Tukey test was used in the Post Hoc tests for the evaluation of the sup-groups. ROC curves were constructed for significantly differing parameters to establish diagnostic cut-off values. A value of $p<0.05$ was considered to be significant.

\section{RESULTS}

The comparison of the age, week of delivery and laboratory findings were depicted in table 1.

When the ages were compared, it was found that the average age of the patients with gestational hypertension was significantly higher than the other two groups $(p=0.0002$ and 0.0001 ), the preeclampsia group and the control group had similar maternal age. The week of gestation at birth were significantly different between the groups $(p=0.0001)$. It was seen that preeclampsia patients gave birth in very early weeks $(p=$ 0.0001 for PE vs control, $p=0.0003$ for PE vs GHT). The GHT group patients delivered an average of two weeks before the control group ( $p=0.003)$. The mean ALT and AST values were different between the groups $(p=0.029$ and $p=0.006$ respectively). The creatinin levels were higher in the PE group and in the GHT group versus the control $(p=0.0001$ for PE vs control and $p=0.0003$ for $G H T$ vs control), but, there was no significant difference between the PE and the GHT. When the subgroups were analysed, there was no difference between the GHT group and the control group, and between the GHT group and PE group in term of the urea and the MPV levels $(p=0.18$, $p=0.48$ respectively). As a result of the tests, the groups' the average levels of $\mathrm{PC}, \mathrm{PMI}$ and PC/MPV were different from the each other. PC and PMI mean values of the preeclampsia group were significantly lower than the control group $(p=0.016$, $p=0.023$ respectively) (Table 1). 
Table 1: Demographic characteristics and Platelet indices of Study Groups

\begin{tabular}{|c|c|c|c|c|}
\hline Variables & $\begin{array}{c}\text { Group 1 } \\
\text { patients with } \\
\text { preeclampsia } \\
\qquad \mathbf{n}=\mathbf{2 1 0} \\
(M e a n \pm \text { SD) }\end{array}$ & $\begin{array}{c}\text { Group 2 } \\
\text { Patients with } \\
\text { Gestational } \\
\text { Hypertension } \\
\text { n=88 } \\
(M e a n \pm \text { SD) }\end{array}$ & $\begin{array}{c}\text { Group } 3 \\
\begin{array}{c}\text { Control Patients } \\
\text { n=140 }\end{array} \\
(\mathrm{Mean} \pm \mathrm{SD})\end{array}$ & $\mathbf{P}$ \\
\hline Age & $30.1 \pm 6.6^{a}$ & $36 \pm 5.6^{a . b}$ & $30 \pm 5.8^{b}$ & $<0.001$ \\
\hline Birth week & $33 \pm 4^{\text {a.d }}$ & $37 \pm 3^{\text {c.d }}$ & $39 \pm 1^{\text {a.c }}$ & $<0.001$ \\
\hline Hemoglobin & $11.4 \pm 1.5$ & $11.5 \pm 1.4$ & $11.8 \pm 1.2$ & 0.13 \\
\hline Hematocrit & $34 \pm 4.3$ & $34.4 \pm 4.0$ & $34.7 \pm 3.0$ & 0.81 \\
\hline WBC & $10463 \pm 3603$ & $10372 \pm 3617$ & $9971 \pm 2318$ & 0.64 \\
\hline ALT & $32.1 \pm 5.54^{\mathrm{e}}$ & $25.9 \pm 4.1$ & $13.07 \pm 5.5^{\mathrm{e}}$ & 0.029 \\
\hline AST & $45.5 \pm 7.1^{\mathrm{c}}$ & $35.1 \pm 2.8$ & $17.9 \pm 5.3^{\mathrm{c}}$ & 0.006 \\
\hline Urea & $31 \pm 7.8$ & $22.45 \pm 8.05$ & $14.6 \pm 3.85$ & 0.18 \\
\hline Creatinin & $0.63 \pm 0.17^{\mathrm{a}}$ & $0.59 \pm 0.05^{\mathrm{d}}$ & $0.46 \pm 0.09^{\text {a.d }}$ & $<0.001$ \\
\hline MPV (fL) & $10.88 \pm 2.46$ & $10.56 \pm 0.10$ & $11.12 \pm 1.17$ & 0.48 \\
\hline $\mathrm{PC}(/ \mu \mathrm{L})$ & $194.009 \pm 65.093^{\mathrm{e}}$ & $203.227 \pm 65.409$ & $222.639 \pm 60.992^{\mathrm{e}}$ & 0.02 \\
\hline PMI & $2,112.5 \pm 808.4^{\mathrm{f}}$ & $2,224.0 \pm 941.0$ & $2,449.6 \pm 603.2^{\mathrm{f}}$ & 0.03 \\
\hline PC/MPV & $17619 \pm 6767^{g}$ & $18600 \pm 5864$ & $20434 \pm 6740^{\mathrm{g}}$ & 0.033 \\
\hline
\end{tabular}

$\mathrm{p}<0.05$ was accepted as statisticaly significant. ${ }^{\mathrm{a}} \mathrm{p}=0.0001,{ }^{\mathrm{b}} \mathrm{P}=0.0002$, $\mathrm{p}=0.003,{ }^{\mathrm{d}} \mathrm{P}=0.0003,{ }^{\mathrm{e}} \mathrm{p}=0.016,{ }^{\mathrm{f}} \mathrm{p}=0.023,{ }^{\mathrm{g}} \mathrm{p}=0.026$. Platelet Count-PC, Mean Platelet Volume-MPV, platelet count $\mathrm{x}$ mean platelet volume-PMI, Platelet count / mean platelet volume-PC / MPV.

Similarly to PC and PMl, the mean PC/MPV levels were different between the groups but this differences was caused by the differency between $\mathrm{PE}$ and control group $(\mathrm{p}=0.026)$.

In the group of the preeclamptic patients, PC, PMI and PC/ MPV cut-off value were $205500 \mu \mathrm{L}, 2303.35 \mathrm{ml} / 103,18083.98$ and sensitivities-specificities of PC, PMI and PC/MPV were $54.6 \%-54.3 \%, 53.6 \%-52.6 \%, 51.6 \%-51.0 \%$ respectively. The confidence intervals of these cut-off values of indices were found to be significant for all three values (table 2 and figure 1).

Table 2: Averages of Platelet Indices in Preeclampsia Patients and Confidence Intervals and Cut-Off Values in ROC Curve

\begin{tabular}{|l|l|l|l|c|c|c|l|}
\hline & $\begin{array}{l}\text { Cut-Off } \\
\text { Value }\end{array}$ & $\begin{array}{l}\text { Sensi- } \\
\text { tivity }\end{array}$ & $\begin{array}{l}\text { Speci- } \\
\text { ficity }\end{array}$ & AUC \pm SE & \multicolumn{2}{|c|}{$\begin{array}{c}\text { 95\% CI } \\
\text { Lower and Upper } \\
\text { Limit }\end{array}$} & P \\
\hline PC $(\mu \mathrm{L})$ & 205500 & $54.6 \%$ & $54.3 \%$ & $0.386 \pm 0.044$ & 0.29 & 0.47 & $\mathbf{0 . 0 1 5 *}$ \\
\hline PMI & 2303.35 & $53.6 \%$ & $52.6 \%$ & $0.391 \pm 0.044$ & 0.30 & 0.48 & $\mathbf{0 . 0 2 1 *}$ \\
\hline PC/MPV & 18083.98 & $51.6 \%$ & $51.0 \%$ & $0.49 \pm 0.045$ & 0.30 & 0.48 & $\mathbf{0 . 0 1 9 *}$ \\
\hline
\end{tabular}

$\mathrm{p}<0.05$ was accepted as statisticaly significant, Area under AUC-Curve, PC:

Platelet count, MVP: Mean Platelet Volume, PMI: Platelet mass index, CI:

Confidence interval
Figure 1: ROC Curve of Platelet Indices in Preeclampsia Patients

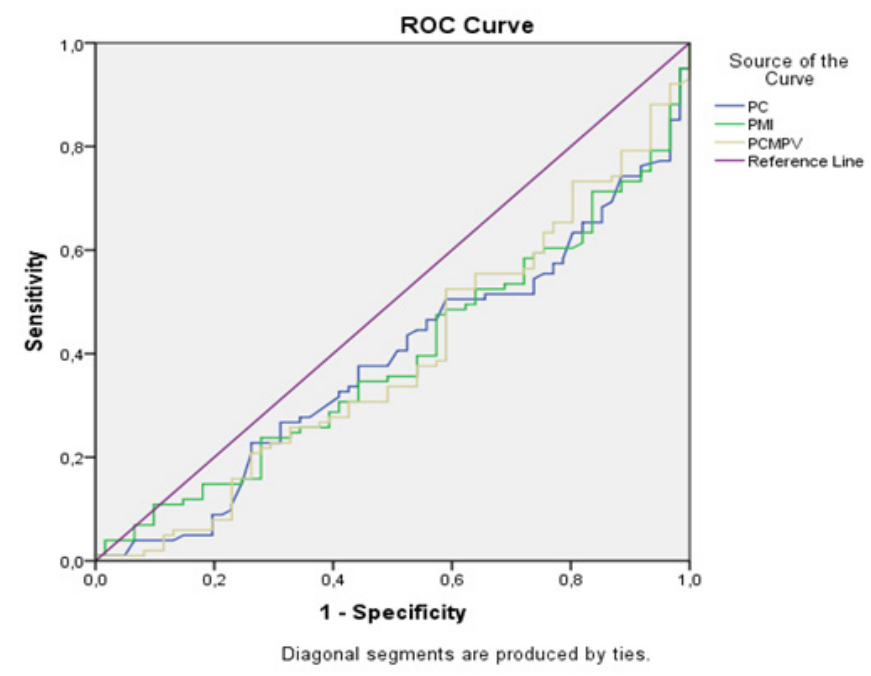

\section{DISCUSSION}

Vasodilation and secondary hypotension normally occur during pregnancy, but hypertension develops as a result of increased intravenous pressure due to vasoconstriction in GHT and preeclampsia. Since endothelial damage does not develop in GHT, platelet count generally does not change significantly. The production and consumption of new platelets from bone marrow in patients with GHT are in balance. However, since destruction is more than production in preeclampsia, thrombocytopenia occurs in these patients in proportion to the severity of the disease (7). Compared with PE, it was observed that micro-particles were less common in patients with $\mathrm{GHT}$, and therefore thrombocytopenia rarely developed (11). In our study, the platelet count in the PE group was lower than the control group. Although the platelet count in the GHT group was lower than the control group, it was not statistically significant. In our study, it was found that there was a significant thrombocytopenia in PE cases and the number of thrombocytes decreased in $\mathrm{GHT}$, but the result was not significant. The PC results in our study were compatible with previous studies (7).

The increase in blood pressure in cases with GHT can also change MPV depending on the shape and volume change in platelets (11). There are studies indicating that MPV values will be higher since the new platelets formed in preeclampsia are larger $(7,13-15)$. In some other studies, it was found that consumption in preeclampsia was higher than production (low PC) but MPV was normal $(7,16,17)$. However, there are many reasons why the studies are different. These; additional diseases in cases are not excluded [diabetes mellitus increases MPV (7)], they are not separated as term-preterm according to 
gestational week $(5,16,17)$, and equipment and devices used when obtaining hemograms. Because of these, there are publications that MPV cannot predict preeclampsia and cannot be used safely (5). In our study, it was found that MPV was low in PE and GHT groups but the result was not significant.

Increased platelet cycle resulting from endothelial damage in patients with preeclampsia leads to an increase in MPV with a new platelet, resulting in a decrease in PC/MPV. Increased blood pressure in patients with GHT causes a decrease in MPV (12), a decrease in platelet life and an increase in thromboxane A2 also causes a decrease in PC (18). Therefore, a decrease in PC/MPV index is expected in GHT cases. A study by Freitas and colleagues found that patients with preeclampsia had a low PC (19). In another study conducted Doğan et al found that not only PC but also PC/MPV value was lower in PE cases than control group (13). In the studies conducted by Yavuzcan et al, MPV did not differ between pregnant women who were PE, pregnant women who were not PE and those who were not pregnant. In the same studies, it was concluded that PC and PC/MVP are stimulating for $\operatorname{PE}(5,20)$. Von Dadelszen et al suggested that the MVP/PC ratio reflects platelet consumption and can be used as a weak indicator of maternal progression in preeclamptic cases (21). In another study, Altınbaş et al did not find a significant relationship between PE and PC/MPV. In our study, PC/MPV index was less than the control group in PE cases, in line with other studies (16). Although the PC/MPV index was lower than the control group, it was not significant due to the decrease in PC in the GHT group.

Another index, PMI, is obtained by multiplying the platelet count by the mean platelet volume. As mentioned earlier, in PE and GHT, while PC decreases with platelet consumption, MPV is expected to increase or not change with new platelet production. Therefore, PMl change in patients with PE and GHT is a matter of curiosity. Gerday et al found that PMI is associated with prolonged PT time without increasing the risk of hemorrhage (22). In a study conducted in the neonatal intensive care unit, Zisk et al found that if the PMI value is taken into consideration in the platelet transfusion, the need for transfusion will decrease by $11.5 \%$ (23). This finding shows that PMI is a valuable marker for platelet function (24). Another study found that with the decrease of PMI in premature infants, findings such as intracranial hemorrhage, which indicate decreased platelet activity, were found and it also found that with the increase of PMl in premature infants, platelet functions increase and intracranial bleeding decreases. In the same studies, PMI was found to be more significant than the platelet count used to evaluate pathology in the second phase of premature retinopathy $(25,26)$. In the review of the studies, it was concluded that PMI shows the platelet activity better than PC (27). In our study, it was seen that PMI was less in preeclampsia and GHT groups than in the control group. In PMI, just like PC/MPV, the difference in the preeclampsia group from the control group was found to be significant. Although the mean of PMI with PE was lower than in patients with GHT and also mean of PMI was less in the GHT group than the control group, this difference between the groups was not significant.

In our study cut off values with the highest sensitivity and specificity for the indices that were significantly differing in $\mathrm{PE}$, such as PC, PC/MPV and PMI, were established. In another study by Dündar et al, when PC cut off value was taken 221000, sensitivity was found to be $69 \%$ and specificity was $71 \%$ (28). Howarth et al found that in low PC and high MPV, the sensitivity was $90 \%$ and the specificity was $83 \%$ (29). In our study, the cut off values of these indices that were significant were determined (PC= 205,500; PC/MPV=18083.98; $P M l=2303.35$ ). According to these cut off values, these indices were found to have moderate sensitivity and specificity in prediction of PE. It was found that the most sensitive and specific index was PC among these indices, and the PC/MPV index was the lowest

In conclusion, evaluation of platelet functions is important in patients with preeclampsia and GHT. Previously, many studies have studied the relationship between PC and MPV with preeclampsia, PC and MPV with GHT. Although there is a consensus on the decreased PC in patients with PE and GHT, there is no consensus on MPV. As a result of the study, it was concluded that MPV is not important in preeclampsia and GHT patients. It was found that PC, PC/MPV and PMI decreased in both PE and GHT patients, but these decreases were significant in patients with preeclampsia. The superiority of our study is that PE and GHT patients were compared in terms of platelet indices and PMI, which have not been studied before, was assessed in these patient groups. The retrospective design and being a single-centered study are the main limitations of the study. In addition, these indices are variable and analyzer dependent. Prospective, multicenter studies with larger sample sizes would be more informative.

Ethics Committee Approval: The ethics committee approval was received for this study from the Ethics Committee of Mersin University Hospital.

Conflict of Interest: No conflict of interest was declared by the authors. 
Financial Disclosure: The authors declared that this study has received no financial support.

\section{REFERENCES}

[1] Chen KH, Seow KM, Chen LR. Progression of gestational hypertension to pre-eclampsia: A cohort study of 20,103 pregnancies. Pregnancy Hypertens.2017;10:230-37

[2] Van Oostwaard MF, Langenveld J, Schuit E, et al. Recurrence of hypertensive disorders of pregnancy: an individual patient data metaanalysis. Am J Obstet Gynecol. 2015;212:1-17.

[3] Adam GK, Bakheit KH, Adam I. Maternal and perinatal outcomes of eclampsia in Gadarif Hospital, Sudan. J Obs Gynaecol. 2009;29(7):619-620.

[4] Kumru P, Aka N, Kose G, et al. The Value of Mean Platelet Volume in Predicting The Severity of Preeclampsia and of Hellp Syndrome. Obstet Gynaecol Reprod Med. 2007;13:9-13.

[5] Ceyhan T, Beyan C, Baser I, et al. The effect of pre-eclampsia on complete blood count, platelet count and mean platelet volume. Ann Hematol. 2006;85:320-2.

[6] Ozdemir S GH, Acar A, Celik C, et al. The Comprasion of Maternal and Fetal Outcomes Pregnancies of Complicated by Moderate to Severe Thrombocytopenia Caused by Gestational Thrombocytopenia Preeclampsia/HELLP Syndrome and Immune Thrombocytopenic Purpura. Obstet Gynaecol Reprod Med. 2008;14:154-8.

[7] Ozdemirci S, Baser E, Kasapoglu T, et al. Predictivity of mean platelet volume in severe preeclamptic women. Hypertens Pregnancy. 2016;35:474-82.

[8] Delmis J. Hypertension in pregnancy. Lijec Vjesn. 2006;128:357-68.

[9] Tzur T, Sheiner E. Is there an association between platelet count during the first trimester and preeclampsia or other obstetric complications later in pregnancy? Hypertens Pregnancy. 2013;32(1):74-82.

[10] Gerday E, Baer VL, Lambert DK, Paul DA, Sola-Visner MC, Pysher TJ, et al. Testing platelet mass versus platelet count to guide platelet transfusions in the neonatal intensive care unit. Transfusion 2009;49:2034-9.

[11] Gonzalez-Quintero VH, Smarkusky LP, Jimenez JJ, et al. Elevated plasma endothelial microparticles: preeclampsia versus gestational hypertension. Am J Obstet Gynecol. 2004;191:1418-24.

[12] Yarlioglues M, Kaya MG, Ardic I, et al. Relationship betwe- en mean platelet volume levels and subclinical target organ damage in newly diagnosed hypertensive patients. Blood pressure. 2011;20:92-7.

[13] Dogan K, Guraslan H, Senturk MB, et al. Can Platelet Count and Platelet Indices Predict the Risk and the Prognosis of Preeclampsia? Hypertens Pregnancy. 2015;34:434-42.

[14] Dundar O, Yoruk P, Tutuncu L, et al. Longitudinal study of platelet size changes in gestation and predictive power of elevated MPV in development of pre-eclampsia. Prenat Diagn. 2008;28:1052-6.

[15] Kanat-Pektas M, Yesildager U, Tuncer N, et al. Could mean platelet volume in late first trimester of pregnancy predict intrauterine growth restriction and pre-eclampsia? J Obstet Gynaecol Res. 2014;40:1840-5.

[16] Altinbas S, Togrul C, Orhan A, et al. Increased MPV is not a significant predictor for preeclampsia during pregnancy. J Clin Lab Anal. 2012;26:403-6.

[17] Yavuzcan A, Caglar M, Ustun Y, et al. Mean platelet volume, neutrophillymphocyte ratio and platelet-lymphocyte ratio in severe preeclampsia. Ginekol Pol. 2014;85:197-203.

[18] Lescale KB, Eddlenmank KE, Cine DB. Ant platelet antibody testing in thrombocytopenic pregnant women. Am J Obs Gynecol. 1996; 174(3): 1014-8.

[19] Freitas LG, Alpoim PN, Komatsuzaki F, Carvalho Md, Dusse LM. Preeclampsia: are platelet count and indices useful for its prognostic? Hematology. 2013;18(6):360-364.

[20] Makuyana D, Mahomed K, Shukusho FD, Majoko F. Liver and kidney function tests in normal and pre-eclamptic gestation - a comparison with non-gestational reference values. Cent Afr J Med. 2002;48(5-6):55-59.

[21] Von Dadelszen P, Magee LA, Devarakonda RM, et al. The prediction of adverse maternal outcomes in preeclampsia. $\mathrm{J}$ Obstet Gynaecol Can 2004; 26:871-79.

[22] Gerday E, Baer VL, Lambert DK, et al. Testing platelet mass versus platelet count to guide platelet transfusions in the neonatal intensive care unit.Transfusion 2009;49(10):20342039.

[23] Zisk JL, Mackley A, Clearly G, Chang E, Christensen RD, Paul DA. Trans $\urcorner$ fusing neonates based on platelet count vs. platelet mass: a randomized fea sibility-pilot study. Platelets 2014;25(7):513-516.

[24] Yavuzcan Ozturk D, Ercin S, Gursoy T, Karatekin G, Ovali F. Platelet mass index: is it a hope for reduction of platelet transfu- 
sion in NICU? J Matern Fetal Neonatal Med 2016;29(12):19261929.

[25] Korkmaz L, Bastug O, Ozdemir A, Korkut S, Karaca C, Akin $M A$, et al. The efficacy of propranolol in retinopathy of prematurity and its correlation with the platelet mass index. Curr Eye Res 2017;42:88e97.

[26] Demir N, Peker E, Ece I, A gengin K, Bulan KA, Tuncer O. Is platelet mass a more significant indicator than platelet count of closure of patent ductus arteriosus? J Matern Fetal Neonatal Med 2016;29:1915e8.

[27] Zisk JL, Mackley A, Christensen RD, Paul DA. Is a small platelet mass associated with intraventricular hemorrhage in very low birth-weight infants? J Perinatol 2011;31:776e9.
[28] Gioia S, Piazze J, Anceschi MM, et al. Mean platelet volume: association with adverse neonatal outcome. Platelets 2007;18:284-8.

[29] Howarth S, Marshall LR, Barr AL, et al. Platelet indices during normal pregnancy and pre-eclampsia. $\mathrm{Br} \mathrm{J}$ Biomed Sci 1999;56:20-2. 